\title{
Exploring Local People's Perception of Ecosystem Services in Djoumouna Periurban Forest, Brazzaville, Congo
}

\author{
V. Kimpouni $\mathbb{D}^{1,2}$ J. D. D. Nzila ${ }^{1}{ }^{1,2}$ N. Watha-Ndoudy, ${ }^{1,3}$ M. I. Madzella-Mbiemo, ${ }^{2}$ \\ S. Yallo Mouhamed $\mathbb{D}^{2}{ }^{2}$ and J.-P. Kampe $\mathbb{D}^{2}$ \\ ${ }^{1}$ École Normale Supérieure (ENS), Université Marien Ngouabi, BP 237, Brazzaville, Congo \\ ${ }^{2}$ Institut National de Recherche Forestière (IRF), BP 177, Brazzaville, Congo \\ ${ }^{3}$ Faculté des Sciences et Technique (FST), Université Marien Ngouabi, BP 69, Brazzaville, Congo
}

Correspondence should be addressed to V. Kimpouni; vkimpouni@yahoo.com

Received 29 December 2020; Revised 9 March 2021; Accepted 12 March 2021; Published 13 April 2021

Academic Editor: Anna Źróbek-Sokolnik

Copyright (c) 2021 V. Kimpouni et al. This is an open access article distributed under the Creative Commons Attribution License, which permits unrestricted use, distribution, and reproduction in any medium, provided the original work is properly cited.

The perception of ecosystem goods and services by local residents is studied in Brazzaville, around the periurban forest of Djoumouna. This study, which documents the ecosystem services provided to communities by this ecosystem facing anthropogenic degradation, evaluates the understanding and consideration of these functions, according to socioprofessional categories. Socioeconomic and ethnobotanical surveys conducted among the group of informants are supported by direct field observations and literature review. The data collected within a $2 \mathrm{~km}$ radius around the forest were subjected to descriptive and statistical analysis. The group of informants, including all socioprofessional strata, was organised into 4 age groups and involved 143 heads of household aged from 15 to over 45 . The survey reveals 14 ecosystem services that fall into three categories. The provisioning services included food, wood energy, pharmacopoeia, and wood services. The regulatory functions cited are maintaining air quality, shade, erosion control, and windbreak. Recognized sociocultural services are the source of income, recreation, and ecotourism, source of inspiration, fishing, initiation sanctuary, and hunting. According to gender, men are more dependent on the forest than women, and those aged 15-25 and over 45 are the most active. The socioprofessional scale shows an unequal exploitation of the forest. The informants, at least for the majority, integrate the notions of the value of ecosystem services, provided by the Djoumouna periurban forest, into their daily lives. Finally, the study highlights the social and ecological value of periurban and urban forests in the daily lives of people and urban resilience.

\section{Introduction}

Straddling the equator, Congo is located in Central Africa and covers an area of $342,000 \mathrm{~km}^{2}$. Savannah (35-40\%) and forest $(60-65 \%)$ are the main plant formations that divide up the territory [1]. Congolese forests represent $12.4 \%$ of the Congo Basin forests and are divided into three main groups: Mayombe (3\%), Chaillu (11\%), and the North Congo Massif with the Upper Sangha (31\%) and Lower Sangha (20\%) [2-4].

The interest of Congolese forests on the triple economic, social, and ecological level is no longer to be justified. These ecosystems are a major lever for the development and the emergence of the Congolese economy [5]. These forests provide society with a set of ecosystem goods and services of national and regional scope. Ecosystem goods and services imply all the direct and indirect benefits that humans derive from ecosystem functioning [6-8]. The resulting benefits fall into three categories [9]. Provisioning (harvesting) services include products such as fuelwood, service wood, food, game, and medicines [10]. Regulating services include climate regulation, carbon sequestration, air pollution removal, watershed water regulation, soil protection, and flood control [11-13]. Sociocultural services relate to natural heritage, recreation, aesthetics, ecotourism, and spiritual values of forests [11].

Notwithstanding this main subdivision, which obscures small-area forest formations, notably urban and periurban 
forests, the direct and indirect ecological functions and roles played by the latter are not negligible in the maintenance of urban equilibrium. Urban and periurban forests are focal points for biodiversity conservation by providing alternative habitats for many plant and animal species [14]. This is the case in Australia, where hundreds of endangered native species depend primarily on urban habitats [15]. These forests also enhance cultural diversity by increasing the resilience of cities to environmental shocks and stressors $[16,17]$. By providing shade and evapotranspiration, urban and periurban forests can lower daytime temperatures by up to $6^{\circ} \mathrm{C}$ depending on the latitude of the city $[12,13,18]$. A large tree can intercept up to 190 liters of water during a rainfall event, thus reducing runoff and the risk of flooding and landslides, which are current phenomena in Brazzaville. These forests purify the air through leaves that act as passive reservoirs by intercepting certain particles [19]; accumulation rates of 10 to $70 \mu \mathrm{g} \cdot \mathrm{cm}^{-2}$ particles in leaves have been recorded in the Aburrá Valley in Colombia [20].

Like all the woody formations in the world, the urban and periurban forests of Brazzaville provide a diverse range of goods and services to society. These products are subdivided into tangible (direct) and intangible (indirect) services. In addition to direct services, the most valued by local residents are wood products (firewood and service wood) and nonligneous forest products (NTFPs), including mushrooms, aromatic, medicinal, and food plants, and game; indirect services are exploited concomitantly. As direct goods and services are essentially related to the extraction, indirect ones are associated with regulation (water and mineral cycles, protection of watersheds and soils, carbon sequestration and climate change mitigation, protection and preservation of biodiversity, cultural and historical heritage, outdoor recreation, and leisure areas) and sociocultural ones.

However, in spite of the well-known benefits to local residents, the urban and periurban forests of Brazzaville are subject to increasingly intense anthropogenic pressures that have led to the disappearance of several of them [21, 22]. In the absence of proven knowledge, these last natural woody formations will disappear like the urban forests of the Tsiéme, the Corniche, the Chad Ravine, and the Glacière, despite the services rendered to the community [3]. In spite of the services provided to the community, human carelessness had come to dominate their existence. The consequences of this anthropization are leading to an erosion of biodiversity and the associated ecosystem goods and services [23]. The aim of carrying out an assessment of the ecosystem services provided by the Djoumouna forest is becoming more than just a necessity in order to gradually awaken the collective consciousness of local residents about the value of these formations in their daily lives. As the notion of ecosystem services is a new issue in the study area, the focus of the study is to explore the perception of the local population of the Djoumouna periurban forest with regard to these services. In fact, data relating to ecosystem services are almost absent from the literature in the region, despite the relevance of the information generated for the purposes of sustainable development in general and, in particular, the wellbeing of populations and the resilience of urban cities.
This study, which documents the ecosystem services provided to communities by this ecosystem faced with anthropogenic degradation, assesses the understanding and consideration of these functions, according to socioprofessional categories. Thus, special emphasis should be placed on these periurban or even natural intraurban training courses, to which public managers pay almost no attention. In this respect, the data from the study, coupled with the bioecological and ethnobotanical findings, should usher in an era of better integration of urban and periurban forest management issues into Brazzaville's urban development plans. Data on the perception of ecosystem services of the riparian's of urban and periurban forests are likely to constitute an argument for the conservation of these formations [24]. This study contributes to meeting the challenges of conserving and sustainably managing urban and periurban forests, with a view to ensuring better living conditions for city dwellers and resilient cities.

The perception of local residents on the ecosystem goods and services derived from the Djoumouna periurban forest will be analyzed according to gender, age group, level of education, marital status, and socioprofessional activity.

\section{Materials and Methods}

2.1. Presentation of the Study Area. The Djoumouna periurban forest $\left(-04^{\circ} 22^{\prime}\right.$ to $-04^{\circ} 35^{\prime} \mathrm{S}$ and $15^{\circ} 09^{\prime}$ to $\left.15^{\circ} 15^{\prime} \mathrm{E}\right)$ develops $24 \mathrm{~km}$ southwest of Brazzaville (Figure 1). This 3.5 ha river formation is irrigated by the Djoumouna, a small permanent tributary of the Congo $[25,26]$. The climate of the Bas-Congolese type $[27,28]$ is marked by a mean annual temperature of $25^{\circ} \mathrm{C}$ with a low annual temperature range of less than $6^{\circ} \mathrm{C}$. The months of March, April, and November are the hottest, while July and August are the coolest $[28,29]$. Annual rainfall varies from 1200 to $1400 \mathrm{~mm}$ [30]. Rainfall begins in late September and lasts from October to May, with a marked decline between January and February. The rainiest months are generally March, April, and November [30]. The annual relative humidity, always above $80 \%$ on average, plays an important role in the vegetation, especially in the dry season, with a low annual hygrometric amplitude. The values of the average daily hygrometric amplitude are $33 \%$ in the rainy season and $46 \%$ in the dry season $[28,30]$. Evaporation varies in the opposite direction of atmospheric humidity and its relative minimum is observed in June and the absolute maximum in August and September [30]. The annual average of insolation is in the range of 1100 to 1800 hours [31, 32].

2.2. Soil. The soils evolving under the Djoumouna forest belong to two classes: highly desaturated ferrallitics whose sum of exchangeable bases $(\mathrm{Ca}, \mathrm{Mg}, \mathrm{K}$, and $\mathrm{Na}$ ) is very low in the $\mathrm{B}$ horizon (of the order of $1 \mathrm{meq} / 100 \mathrm{~g}$ ) and a saturation rate of the absorbent complex lower than $20 \%$ [33].

2.3. Flora and Vegetation. At the phytogeographic scale, the periurban forest of Djoumouna belongs to the District of 

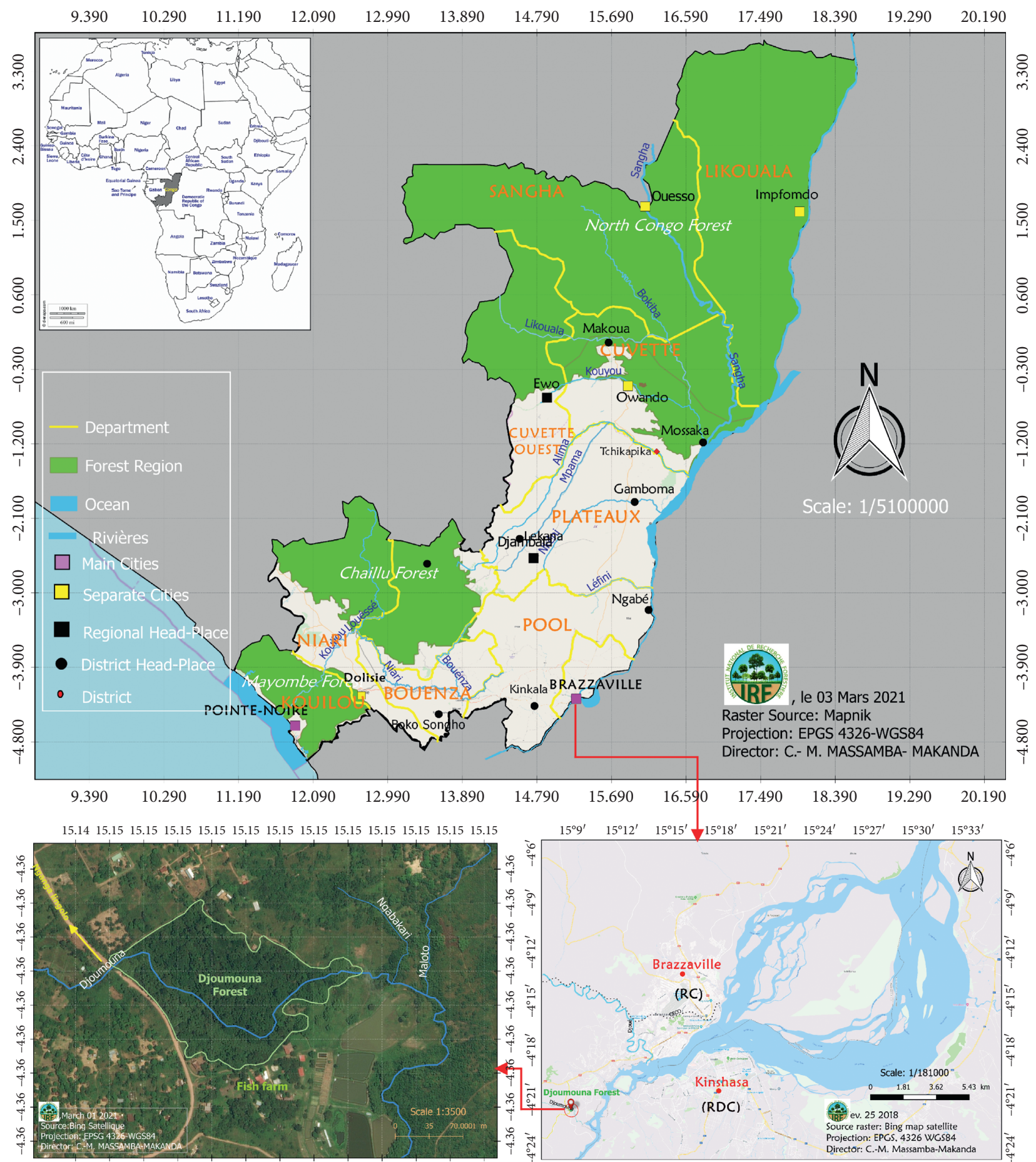

$15.14 \quad 15.1515 .1515 .1515 .1515 .1515 .15 \quad 15.15 \quad 15.15 \quad 15.15 \quad 15.15 \quad 15.15 \quad 15.15$

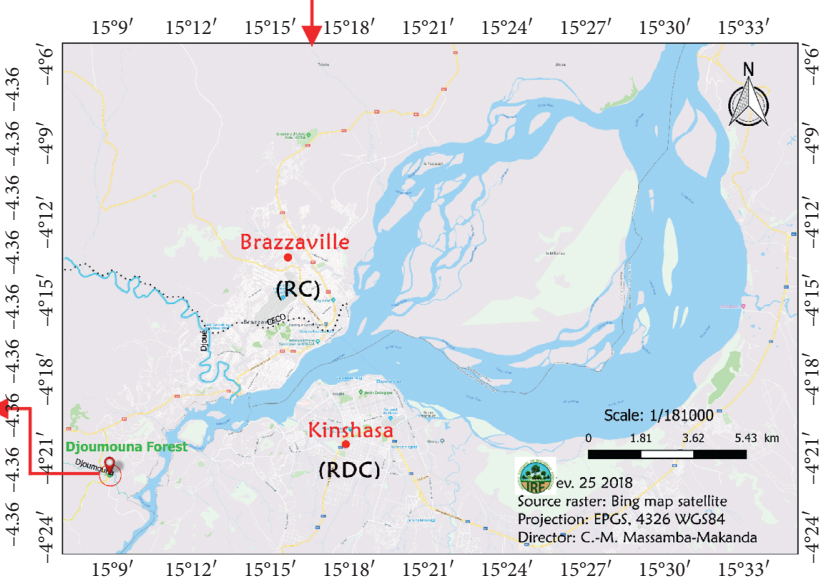

Figure 1: Congolese forest presentation and location of the study area.

Cataractes, confined between the districts of Niari and Léfini. This mesophilic and tropophilic formation presents a flora based on species such as Millettia laurentii, Pentaclethra eetveldeana, Staudtia kamerunensis, Petersianthus macrocarpus, Macaranga monandra, and Trichilia monadelpha [31,34]. Anthropic degradation induces secondary formations, of which the heliophilic pioneer species and Elaeis guineensis are characteristic.
The forest cover of Brazzaville, once lush and very extensive in the 1960s, included 5 natural woody formations that have only known varying fortunes as a result of anthropogenic activities $[3,25,31]$. In about ten years, the town lost four of its intra- and periurban woody formations, namely, the Tsiéme, Glacière, Chad Ravine, and Corniche $[3,31]$. As for the Patte d'Oie urban forest, about 240 ha were classified by Order no. 3037 of 13 August 1938 of the 
Governor General of French Equatorial Africa (AEF), with a view to conserving this ecosystem. Decree no. 2009-149 of 8 May 2009, which is currently in force, reduces the area of this reserve to about $95 \mathrm{ha}$, including patches of natural and artificial forest, administrative and university buildings, and sports facilities [3]. Currently, the natural forest cover of Brazzaville is estimated at less than $10 \%$ of its original area [3]. Finally, for the same reasons, the Djoumouna Forest Reserve, which until 1998 covered around 8.5 ha along the banks of the Djoumouna River, has lost almost $50 \%$ of its cover over the last 20 years or so $[25,26]$. The Djoumouna periurban forest currently covers an area estimated at 4.30 ha, of which 3.5 ha are developed exclusively on a portion of the left bank, a private concession of the Catholic Church housing the Congo Scout camp.

\section{Material}

The plant material at the centre of this study consists essentially of an inventory of woody plants (trees, shrubs, and lianas) and grasses in the Djoumouna periurban forest. The identification of the different taxa was done in situ for the most common ones. The others were identified in the national herbarium (IEC) by comparison of herbarium specimens and diagnoses of the flora of Central Africa, Gabon, and Cameroon. The ordination is based on the [35], while the adopted nomenclature results from [36]. As for the ichthyofauna, it is native to the Djoumouna River, while the terrestrial fauna (mammalian, avian, entomological, and herpetological) comes from the forest and its surroundings.

\section{Methods}

The survey, conducted from 6 to 25 September 2018, is based on an ethnobotanical and socioeconomic questionnaire. It integrates direct field observations and literature review. The target population consists of the residents of the Djoumouna periurban forest.

4.1. Study Area Zoning. The data were collected in the supposed zone of influence of the Djoumouna forest, which extends over a radius of $2 \mathrm{~km}$ around the said formation (Figure 2). This zone of influence was divided into four $500 \mathrm{~m}$ wide concentric bands called "zones," considering the forest as the zero (0) point. Zone 1 is located between the forest and $500 \mathrm{~m}$ radius (very close zone); Zone 2 between 500 and $1000 \mathrm{~m}$ radius (close zone); Zone 3 between 1000 and $1500 \mathrm{~m}$ radius (remote zone); and finally, Zone 4 between 1500 and $2000 \mathrm{~m}$ radius (very remote zone). This zoning has been subdivided into four dials: dial 1 covering the northeast part; dial 2 covering the southeast part; dial 3 covering the southwest part; and dial 4 covering the northwest part [37].

4.2. Socioeconomic and Ethnobotanical Surveys. Surveys involving 264 households helped to understand the perceptions of the people living in the Djoumouna forest on the ecosystem goods and services derived from the forest. The survey is based on a 47-question questionnaire, corresponding to three sections: identification of the respondent, authentication of the Djoumouna periurban forest assets, and investigation of the ecosystem services associated with the forest.

The questionnaire is based on multiple-choice questions relating to the identification of tangible (fruit, wood, and medicinal products) and intangible benefits (improvement of soil fertility, fight against erosion, cultural and social aspects, etc.) derived from this forest area. The choice of households surveyed was made at random, in the different zones of the dials, and the geographical coordinates of each of them were recorded. These parameters take into account the geographical position and distance of the riparian from the Djoumouna forest.

4.3. Data Processing. The survey data were manually tabulated before processing with Sphinx Plus 2 software, which allows results to be generated directly using either univariate or bivariate analysis techniques. The ecosystem services cited by respondents were classified into three categories based on the Millennium Ecosystem Assessment [9]: provisioning services (products derived from ecosystems such as food, timber, fiber); regulating services (indirect benefits from ecosystem processes); and sociocultural services (intangible benefits from ecosystems such as spiritual and religious benefits, recreation, and ecotourism). Supporting services were not included in this study, due to the risk of double counting. Indeed, support services can be considered as intermediary services, enabling the final services to be obtained. Taking them into account would be tantamount to considering twice the same function performed by the ecosystem and from which the population benefits $[38,39]$.

4.4. Ethnobotanical Indicators. The data collected and classified were analyzed with some classic ethnobotanical indicators.

4.5. Frequency of Citation. Citation frequency (CF) was calculated for each ecosystem service category:

$$
\mathrm{CF}=\left(\frac{\text { number of citations }}{\text { number of respondents }}\right) \times 100 \text {. }
$$

4.6. Use Value. For each category of ecosystem service, a use value (UV) defined in [40] was calculated. The use value is a way of expressing the relative importance of ecosystem services for the population [36-44].

$$
\begin{array}{r}
\mathrm{UV}=\frac{\sum_{i}^{n} U_{i}}{n}, \\
\text { either } \mathrm{UVt}=\sum_{1}^{p} \mathrm{UV},
\end{array}
$$

where $U_{i}$ is the number of citations for each ecosystem service and $n$ is the total number of informants. 


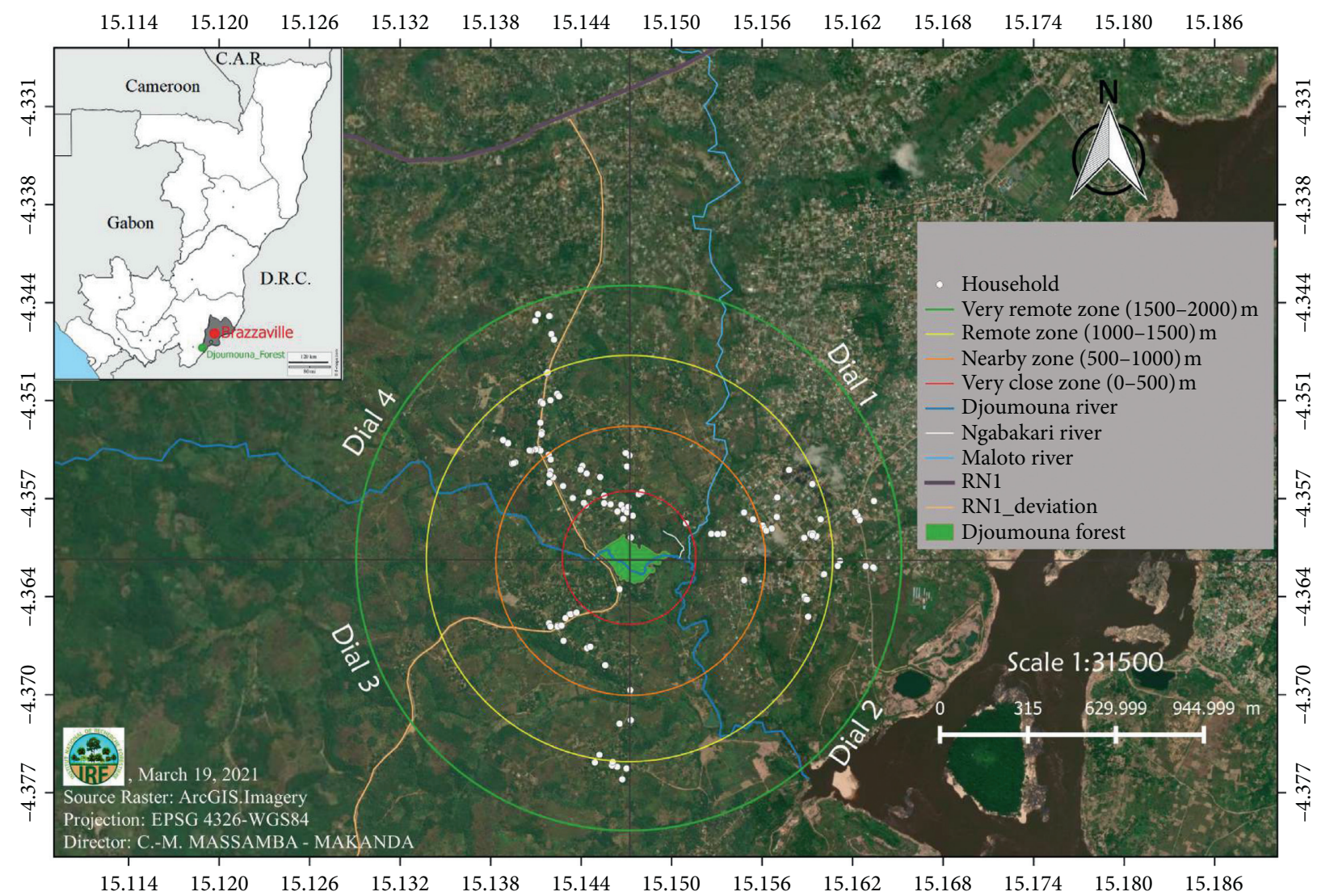

Figure 2: Location of the Djoumouna periurban forest and sampling plan.

4.7. Informant Consensus Factor. The informant consensus factor (ICF) defined in [44] is generally used in the field of ethnomedicine to identify culturally important species, agree on their uses, and possibly consider further studies on them [44-46]. The value of the ICF varies between 0 and 1 and indicates a high consensus when it tends towards 1 . In this study, the ICF was calculated for each of the three categories of ecosystem services:

$$
\mathrm{ICF}=\frac{(\operatorname{Nur}-N 1)}{(\operatorname{Nur}-1)},
$$

where Nur is the number of citations in each ecosystem service category and $\mathrm{Nt}$ is the total number of ecosystem services comprising it.

4.8. Fidelity Level. This indicator made it possible to calculate the level of fidelity (LF) of informants on the perception of ecosystem services associated with the Djoumouna forest. This indicator was calculated according to the formula described in [47]:

$$
\mathrm{LF}=\left(\frac{N_{p}}{N}\right) \times 100,
$$

where $N p$ is the number of people who cited a type of ecosystem service or use and Nis the total number of people who derive some ecosystem service from it.

\section{Results}

5.1. Data on the Group of Informants. Among 264 households surveyed, almost 3/4 (73\%) agreed to complete the questionnaire, $19 \%$ of whom claimed not to be aware of the existence of the Djoumouna forest. Conversely, 27\% refused to take part in the exercise. Taking gender into account, the group of informants is composed almost equally.

For 143 households surveyed, nearly 3/4 (72.8\%) are located in equal proportions in zones 2 and 3. Zones 1 and 4, on the other hand, are home to $11.2 \%$ and $16.1 \%$ of households, respectively. According to georeferencing, the informants are classified according to three main axes: east (Dial 1), southwest (Dial 3), and northwest (Dial 4).

The subjects surveyed in each household are between 15 and over 45 years of age. The characterization of this population by age group reveals 4 age brackets with a difference of 10 years (Table 1).

In relation to education, the majority of informants are at the secondary level (56\%). The remaining portion of the educated is composed of primary $(31.5 \%)$ and university $(2.8 \%)$ levels. Finally, the unschooled fringe corresponds to $9.8 \%$.

Marital status, all types combined, reveals that $54.6 \%$ of informants are married; $42 \%$ are single, and finally, $3.5 \%$ are divorced. The analysis of socioprofessional categories shows that the group of informants is composed of more than $3 / 4$ workers and the remaining portion is made up of students 
TABle 1: Synopsis of the informant group.

\begin{tabular}{lcc}
\hline Age group & Individuals number & Contribution $(\%)$ \\
\hline $15-25$ years & 40 & 28,0 \\
$25-35$ years & 20 & 14,0 \\
$35-45$ years & 24 & 16,8 \\
45 years and over & 59 & 41,3 \\
Total & 143 & 100 \\
\hline
\end{tabular}

(11.2\%), civil servants (6.3\%), unemployed (2.8\%), and retired people $(2.1 \%)$.

5.2. Ecosystem Services Provided by the Djoumouna Forest. The riparian's of the Djoumouna periurban forest identified fourteen ecosystem services in three categories (Table 2). The provisioning services include food, fuelwood, traditional medicine, and wood services. Regarding regulatory functions, riparian cited maintaining air quality, shade, erosion control, and the role of windbreaks. With regard to sociocultural services, the following are recognized: source of income; recreation and ecotourism; source of inspiration; fishing; initiation sanctuary; and hunting. Analysis of the number of citations reveals a clear dominance of regulatory services over sociocultural and provisioning. This observation, almost the opposite of what is often expressed, is based on two facts: the scarcity of natural resources due to the high level of anthropization and the literacy rate within the group of informants.

5.3. Provisioning Services. Almost half of the people living in the Djoumouna forest have recognized the food function provided by this ecosystem, and more than $1 / 4$ have recognized the provision of wood energy (Figure 3(a)). These elements being palpable, this evidence is based on more than one factor of which the impoverishment of communities would be the main source. However, its state of anthropization is such that the allocation of genetic resources no longer allows this woody formation to sufficiently meet the basic needs of the populations, particularly in terms of service wood and traditional pharmacopoeia.

5.4. Regulatory Services. With the exception of the windbreak function, for which the number of citations by riparian in the Djoumouna forest is less than 25\%; all others cover more than the remaining 3/4, overall (Figure 3(b)). Living in the tropics and particularly in the $4^{\circ}$ South latitudes, climatic conditions are such that populations are well informed about the value of intangible services, especially trees growing in housing plots. The low proportion of citations could be due to a lack of perception of the benefits of the forest by the majority of the informants. Thus, remoteness may be a factor that influences the perception of the populations.

5.5. Sociocultural Services. The sociocultural services provided by the Djoumouna forest are very diverse. Those that received more than $75 \%$ citations overall were income source, recreation and ecotourism, and finally, source of inspiration. The services related to the initiation sanctuary and hunting with the lowest citation rates appear marginal (Figure 3(c)). This ecosystem provides various species of mushrooms, caterpillars, insect larvae, small rodents, birds, etc. The low rate of citation of services would be related to the low level of floristic and specific wealth of this ecosystem. Apart from these ecological facts, the footprint of anthropization is not an insignificant fact, as is supported by the source of income to which fishing and hunting would be added. As for the other aspects, society is not sufficiently prepared for the rational exploitation of these services. The highest citation rates would be associated with the middle class of the informant group.

5.6. Use Value of the Djoumouna Forest. The use value (UV) of ecosystem services as a whole ranges from 0.65 to 2.04 . For functions, values range from 0.03 to 0.61 . The total use value (UVt) is 3.85 (Table 2). The low values of this parameter are indicative of a deficit in the exploitation of these products by the population. Given the level of impoverishment of the population and the benefits associated with tangible goods, in particular, this ecosystem is no longer able to satisfy the duality of provisioning and demand.

\subsection{Consensus Factor Informants of Different Ecosystem} Services. Regulatory services are the most cited, with 53\% of the residents of the Djoumouna periurban forest. Far behind and in order of importance are the sociocultural services, which have a citation rate of $30.12 \%$, and finally, provisioning services with $16.87 \%$. These data reveal that the consensus factor of informants for the different categories of ecosystem services ranges from 0.96 to 0.98 (Table 2). This index shows unanimity of use of products derived from this ecosystem by informants. In view of this, the gene pool should be managed rationally to ensure the perpetuation of knowledge and, with it, the forest entity for its indirect services.

5.8. Level of Fidelity of Different Ecosystem Services. The most prominent ecosystem services are associated with the regulation service, including maintenance of air quality and shade. Considered individually, each service receives less than $25 \%$ of the fidelity level. The dispersion of the fidelity level means that the rate of each ecosystem service ranges from 0.9 to $15.8 \%$. The range of values for the overall level of fidelity by service category is between 16.9 and $53 \%$ (Table 2). Monitoring of this parameter reveals that these services are very little used by the population. This phenomenon could result from the high level of anthropization that has severely affected the genetic resources of this periurban forest. As direct goods are often the most prized, their use highlights regulating services such as shade, air quality, and the fight against erosion. 
TABLE 2: Ethnobotanical value of the three categories of ecosystem services.

\begin{tabular}{|c|c|c|c|c|c|c|c|c|}
\hline Categories & Ecosystem services & $U_{i}$ & UV & $\mathrm{LF}$ & $\Sigma U_{i}$ & UVt & ICF & $\Sigma \mathrm{LF}$ \\
\hline \multirow{4}{*}{ Provisioning services } & Human food & 42 & 0.29 & 7.6 & \multirow{4}{*}{93} & \multirow{4}{*}{0.65} & \multirow{4}{*}{0.96} & \multirow{4}{*}{16.9} \\
\hline & Wood energy & 25 & 0.18 & 4.5 & & & & \\
\hline & Traditional pharmacopoeia & 14 & 0.10 & 2.5 & & & & \\
\hline & Service wood & 12 & 0.08 & 2.2 & & & & \\
\hline \multirow{4}{*}{ Regulatory services } & Maintaining air quality & 87 & 0.61 & 15.8 & \multirow{4}{*}{292} & \multirow{4}{*}{2.04} & \multirow{4}{*}{0.98} & \multirow{4}{*}{53} \\
\hline & Shade & 84 & 0.59 & 15.3 & & & & \\
\hline & Erosion control & 71 & 0.49 & 12.9 & & & & \\
\hline & Windbreak role & 50 & 0.35 & 9.1 & & & & \\
\hline \multirow{6}{*}{ Sociocultural services } & Source of income & 48 & 0.34 & 8.7 & \multirow{6}{*}{166} & \multirow{6}{*}{1.16} & \multirow{6}{*}{0.96} & \multirow{6}{*}{30} \\
\hline & Recreation and ecotourism & 44 & 0.31 & 8.0 & & & & \\
\hline & Source of inspiration & 35 & 0.24 & 6.4 & & & & \\
\hline & Fishing & 21 & 0.15 & 3.8 & & & & \\
\hline & Initiation sanctuary & 13 & 0.09 & 2.4 & & & & \\
\hline & Hunting & 5 & 0.03 & 0.9 & & & & \\
\hline Total & & 551 & 100 & 100 & 551 & 3.85 & 2.90 & 100 \\
\hline
\end{tabular}

$U_{i}$ : number of citations for each ecosystem service; $\Sigma U_{i}$ : number of citations in each ecosystem service category; UV: use value of each ecosystem service; UVt: sum of use values in each ecosystem service category; LF: level of fidelity.

\section{Gender Perceptions of Ecosystem Services}

6.1. Provisioning Services. Men are the most active in the exploitation of ecosystem services in the provisioning services category. The focus is on food with $40 \%$ of the citations (Figure $4(\mathrm{a})$ ). With regard to the data, the relationship between the number of citations and gender on diet marks the low production state of this ecosystem. Indeed, the dietary trait is not supported not by the gathering species other than mushrooms, but by wildlife products. It should be noted that hunting and/or trapping is an almost exclusively male activity. As for activities where women excel, the scarcity of products following anthropization practically excludes this group of forest users. By considering the whole from a statistical point of view, the Mann-Whitney test $(P$ value $0.38>0.05)$ reveals that men and women benefit equally from the provisioning services generated by the Djoumouna periurban forest. Thus, men's hyperactivity on these services is only relative.

6.2. Regulating Services. Men are more alert to regulatory services than women. Both genders cite shading, maintenance of air quality, and erosion control (Figure 4(b)). This result would be the consequence of an empirical education associated with urban arboriculture and mainly trees from housing concessions. In addition to this aspect, the high rate of educated informants could play in favor of these preferences. In this respect, men symbolize a favored and dynamic group for school training, compared to women who are often victims of sociocultural constraints. In the perception of regulation services induced by the Djoumouna periurban forest, the Mann-Whitney test $(P$ value $0.030<0.05)$ reveals significant gender differences. This confirmation of the place of men in the management of regulatory services would be associated with the natural distribution of tasks and functions within this culture.
6.3. Sociocultural Services. The operation of sociocultural services is in favor of men over women. Although the trend is the same within both genders, men's quotations are far above those of women. Recreation and ecotourism are favored over sources of inspiration and income, and hunting (Figure 4(c)). The primacy of men's exploitation of sociocultural services would be correlated with the difference in the education of boys and girls. The fact of considering the sociocultural aspects of the two genders differently would explain the high number of male citations for the services provided by forests in general. The very limited level of the forest's genetic resources, especially those associated with female activities, is a hindrance for this group of operators. Following the exploitation of the benefits due to sociocultural services in the Djoumouna periurban forest, the Mann-Whitney test $(P$ value $0.04<0.05)$ reveals significant differences between genders. The activities associated with this component are mostly devolved to men, a consequence of the social values embodied by women.

\section{Perceptions of Ecosystem Services by Age Group}

7.1. Provisioning Services. The four selected provisioning services are mostly cited in the 15- to 25-year age group. This activism is noted for all ecosystem services in this category. It is also materialized in all age groups, but to a much lesser degree of citation (Figure 5(a)). The craze of the 15- to 25year-olds could easily be explained by the fact that only this bracket finds satisfaction in what remains as a gene pool, especially wildlife. It should be noted that this situation is amplified by anthropization, which has seriously impacted the plant genetic resources of this forest ecosystem, likely to attract the other age groups. With regard to the provisioning services generated by the Djoumouna periurban forest, the Kruskal-Wallis test $(P$ value $0.18>0.05)$ does not highlight significant differences between subjects of different age 


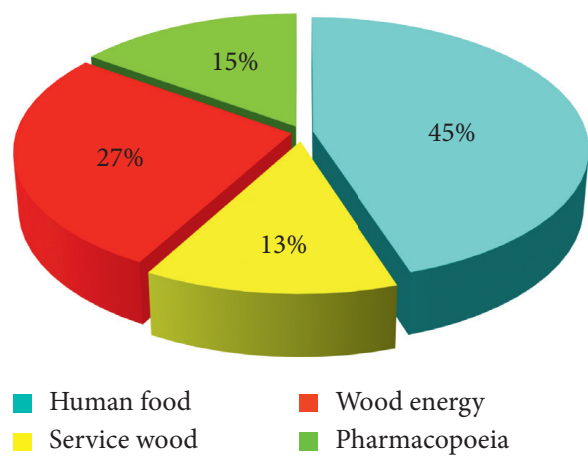

(a)

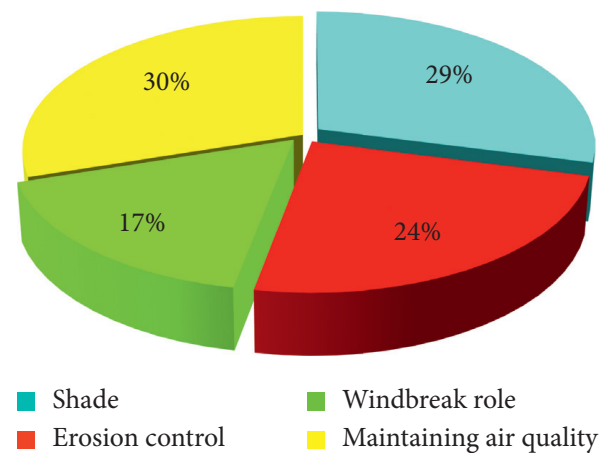

(b)

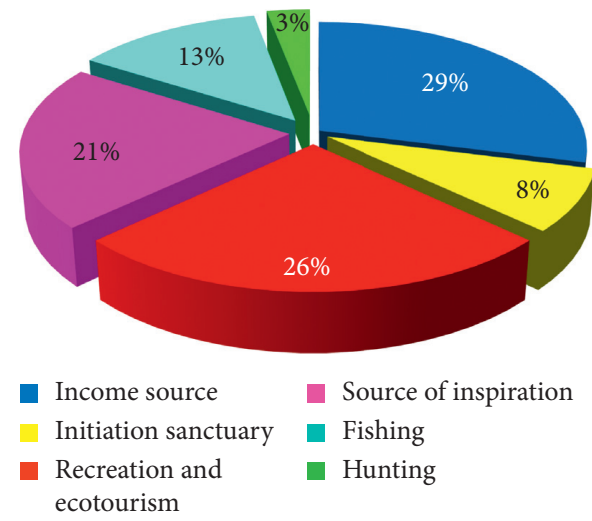

(c)

Figure 3: Ecosystem services provided by the Djoumouna forest: frequency of citation of sampling services (a); frequency of citation of regulatory services (b); frequency of citation of sociocultural services (c).

groups. This result reveals that the dominance of the 15- to 25 -year age group is only relative. Indeed, everyone benefits equally from the benefits provided by the Djoumouna periurban forest.

7.2. Regulating Services. The majority of regulatory functions are recognized in the 15- to 25-year age group (Figure 5(b)). Among these, shading, maintenance of air quality, and erosion control are the most cited. This trend is expressed almost with less acuity in the other age groups. The high number of citation rates would be related to the 15- to 25-year age group within the informant group. As these services embody the virtues of trees in general, the population has an assimilated perception of the benefits derived from the subjects of the housing plots. According to the Kruskal-Wallis test ( $P$ value $0.63>0.05$ ), no significant difference was noted between individuals of different age groups on the benefits of regulation services dependent on the Djoumouna periurban forest. As with provisioning services, no one age group benefits more than others in the operation of all regulation services.

7.3. Sociocultural Services. Residents of all age groups favored the source of income, depending on the number of citations. Recreation and ecotourism, the source of inspiration, and fishing followed (Figure 5(c)). The 15- to 25year-olds are the most active segment of the informant group and their needs can only be met by using forestry services. To this end, these 15- to 25-year-olds rake in all the available forest resources, concomitantly amplifying anthropization and phytogenetic exhaustion. According to the Kruskal-Wallis test $(P$ value $0.06>0.05)$, no significant differences were revealed between individuals of different age groups in relation to the sociocultural services resulting from the Djoumouna periurban forest. This result is justified insofar as the majority of users would be neocitizens whose traditional education means that a subject of about fifteen years, albeit a minor, would have to be autonomous in order to lead his or her life.

\section{Perception of Ecosystem Services by Education Level}

The perception of ecosystem services by residents of the Djoumouna periurban forest is not correlated to the level of study. Whatever the service considered (provisioning services, regulating services, and sociocultural services), the Kruskal-Wallis statistical test does not reveal significant differences. All the observations of dominance made are purely relative. Indeed, the users would be empirically educated on the exploitation of the materials that guarantee their existence. 


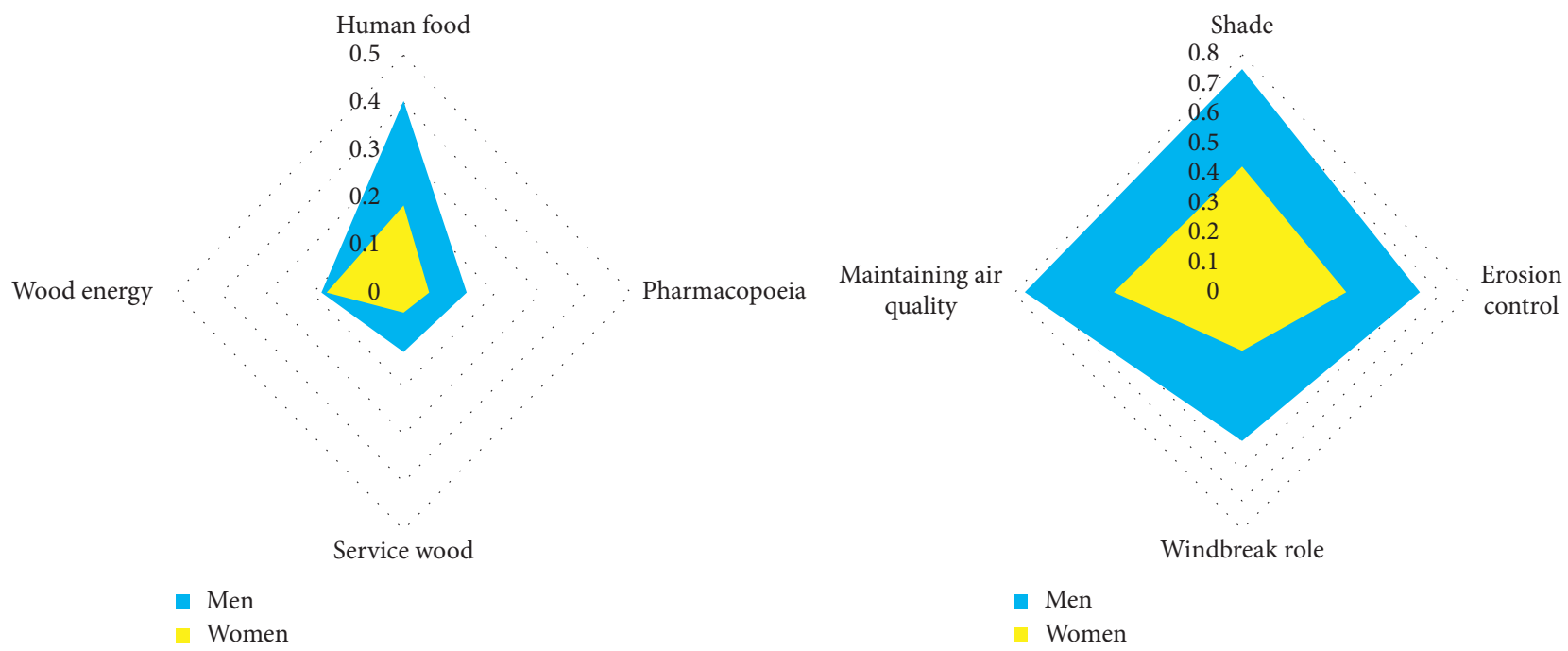

(a)

(b)

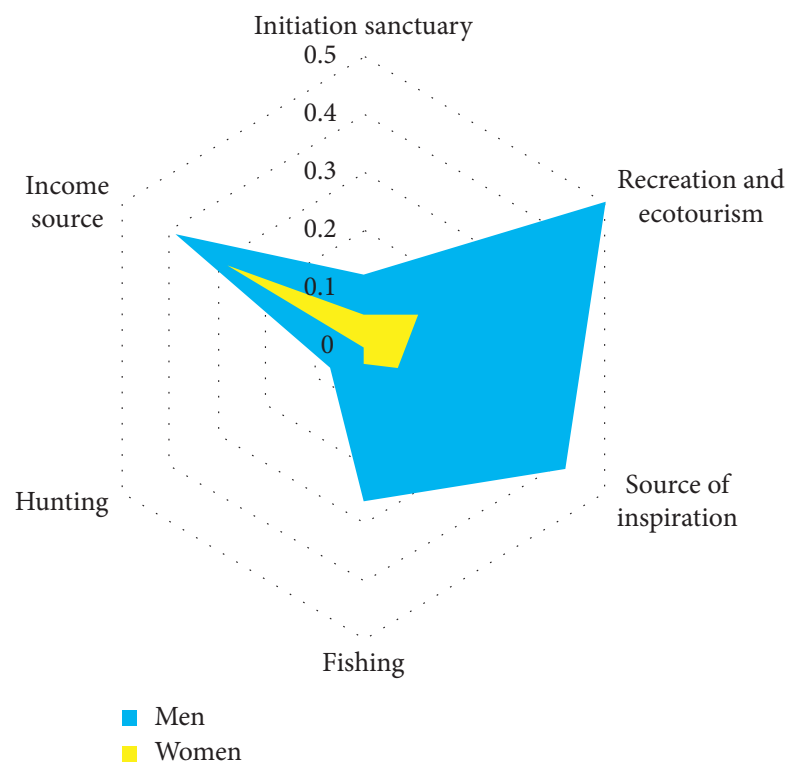

(c)

Figure 4: Gender and perceptions of ecosystem services (\%): frequency of citation of sampling services (a); frequency of citation of regulatory services (b); frequency of citation of sociocultural services (c).

8.1. Provisioning Services. The level of education has almost no effect on the perception of the people living in the Djoumouna forest. Whatever the level, the number of citations is almost the same for all ecosystem services, except wood energy (Figure 6(a)). A detailed analysis of the level of education reveals a proportional evolution between the level of education and the perception of ecosystem services. In connection with the level of study of the individuals, with regard to the provisioning services provided by the Djoumouna periurban forest, the Kruskal-Wallis test ( $P$ value $0.68>0.05)$ did not reveal any significant differences. Since harvesting services are dependent on the good health of the ecosystem, this would be explained by the level of anthropization, the consequence of which is the allocation of resources in terms of quality and quantity.
8.2. Regulating Services. Residents' perceptions of regulatory services are influenced by educational attainment. People at the university level (over 60\%) favored maintaining air quality and the role of windbreaks. Those at the primary and secondary levels have more or less the same perception of the regulating services (Figure 6(b)). Educational attainment significantly influences the perception of ecosystem services and more specifically those of regulation. Indeed, these intangible elements are still not easily understood. Depending on the level of study, the Kruskal-Wallis test $(P$ value $0.86>0.05$ ) shows no significant differences between subjects on the benefits relating to regulation services in the Djoumouna periurban forest. The values of regulatory services are of secular use in this society, at the traditional limit, and confronted with the hazards of nature. 


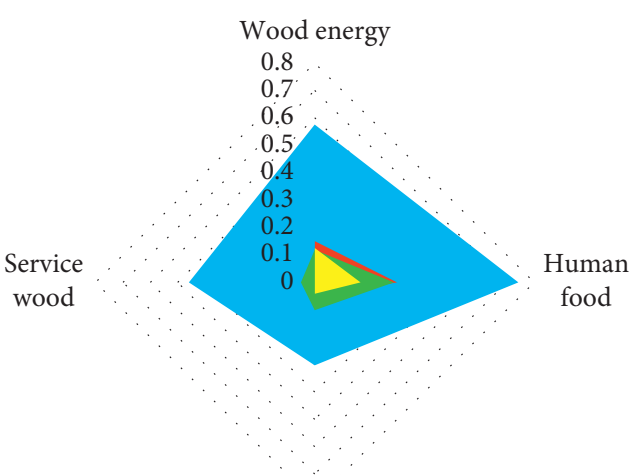

Pharmacopoeia

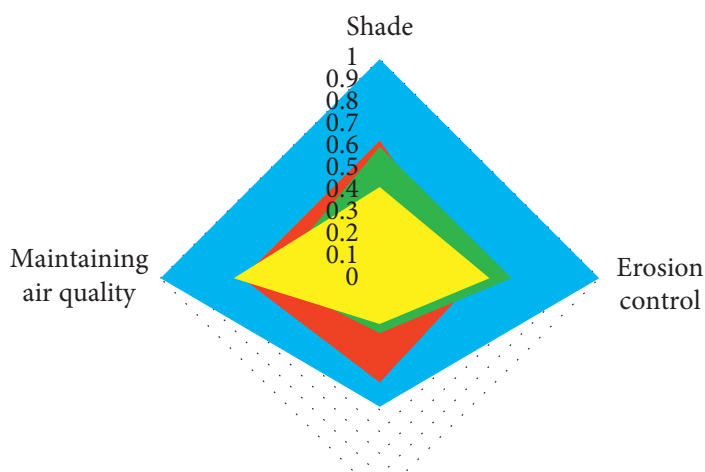

Windbreak role

$$
\begin{array}{ll}
15-25 \text { years } & 45 \text { years and over } \\
25-35 \text { years } & 35-45 \text { years }
\end{array}
$$

(a)

$$
\begin{array}{ll} 
& 15-25 \text { years } \\
& 25-35 \text { years } \\
45 \text { years and over } & 35-45 \text { years }
\end{array}
$$

(b)

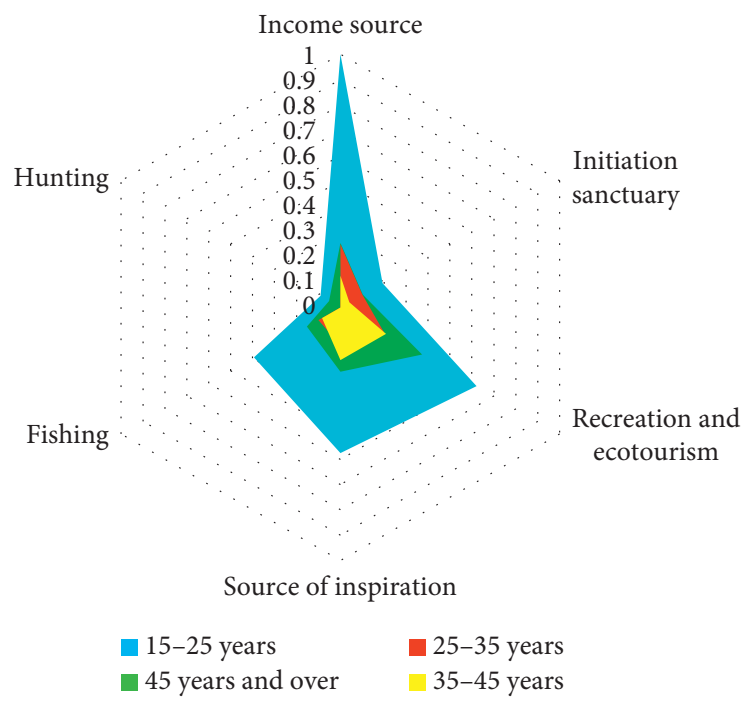

(c)

Figure 5: Perception of ecosystem services by age group (\%): frequency of citation of sampling services (a); frequency of citation of regulatory services (b); frequency of citation of sociocultural services (c).

8.3. Sociocultural Services. Regardless of the level of education of local residents, recreation and ecotourism are, in that order, the most prized ecosystem services, both as a source of income and inspiration. Fishing, hunting, and cultural remain marginal (Figure 6(c)). Perception of sociocultural services is associated with educational attainment. The higher the level of education, the wider its footprint should be, but the low level of diversification of this ecosystem is a major handicap in reading this table. In relation to the sociocultural services resulting from the Djoumouna periurban forest, no significant difference was revealed by the Kruskal-Wallis test $(P$ value $0.42>0.05)$ on the level of education of individuals. The low level of exploitation of sociocultural services would be based on the high level of degradation of this ecosystem, which has strongly affected natural resources.

\section{Perception of Ecosystem Services by Marital Status}

Regardless of the ecosystem service under consideration, the statistical data reveal that there are no significant differences in the different cases or even services.

9.1. Provisioning Services. Depending on marital status, single people are the most active group in the exploitation of ecosystem services. Except for the traditional pharmacopoeia where divorced people are dominant, single people stand out in terms of the number of citations. Fine analysis of the number of citations by group and ecosystem service shows that there is a very little divergence of use associated with status (Figure $7(\mathrm{a})$ ). The low level of use of this 


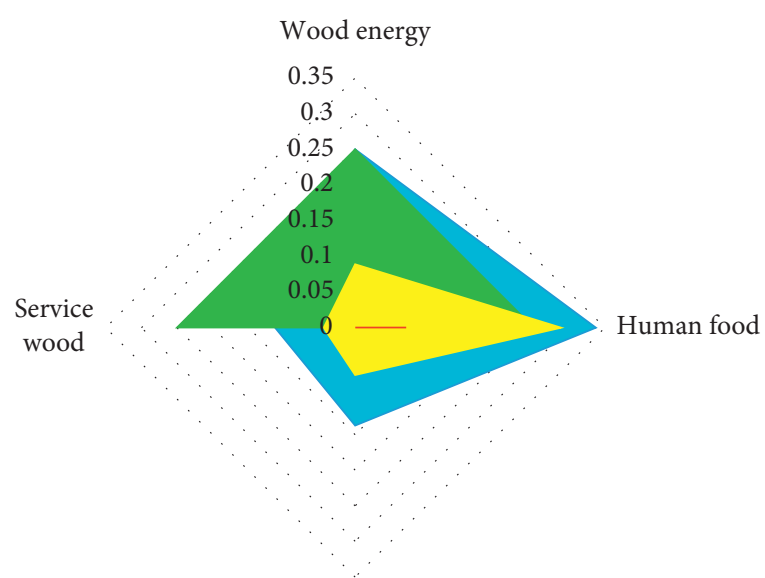

Pharmacopoeia

$$
\begin{array}{ll}
\text { Secondary } & \text { Primary } \\
\text { University } & \text { Unschooled }
\end{array}
$$

(a)

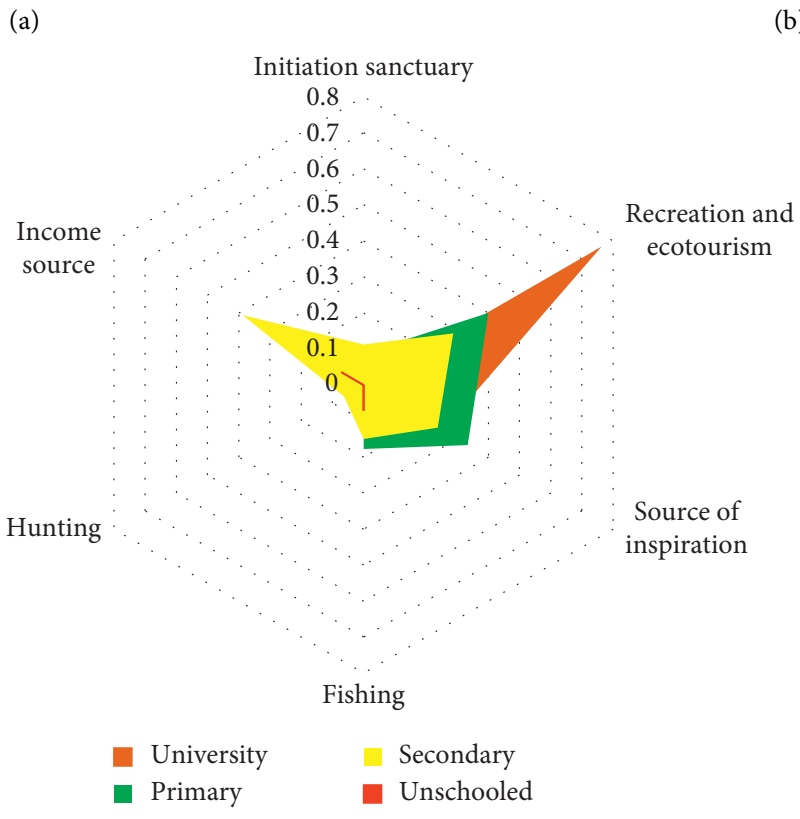

(c)

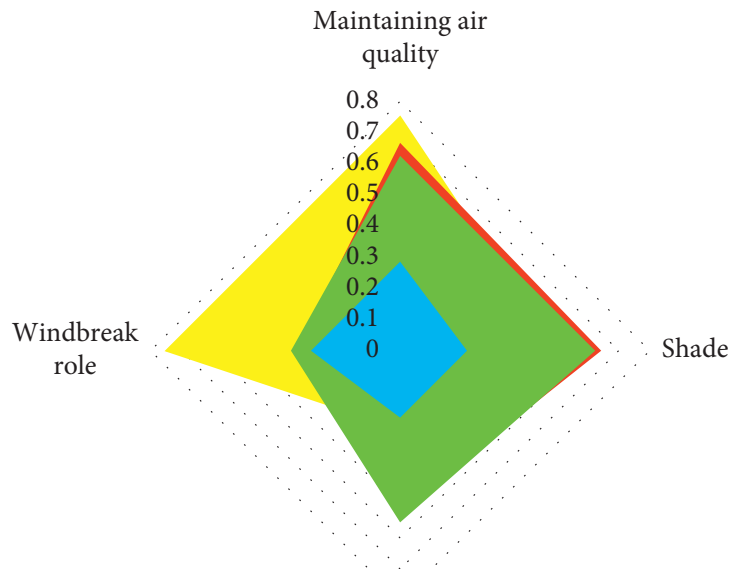

Erosion control

$$
\begin{array}{ll}
\text { University } & \text { Secondary } \\
\text { Primary } & \text { Unschooled }
\end{array}
$$

(b)

FiguRE 6: Perception of ecosystem services by education level (\%): frequency
regulatory services (b); frequency of citation of sociocultural services (c).

ecosystem and exploitation of resources would be inherent to the lack of supply. As pointed out, this supply of natural resources provided is very often the victim of its very extensive anthropization. However, it should be noted that single people (single and divorced) are more exposed or even vulnerable to the vicissitudes of society. In order to satisfy their daily life, natural ecosystems are most often, transformed into a source of reserves on the ground for this social category. In the exploitation of the provisioning services generated by the Djoumouna periurban forest, the Kruskal-Wallis test $(P$ value $0.57>0.05)$ does not show any significant difference between the individuals making up the age groups.
9.2. Regulating Services. Regulation functions are popular with local residents regardless of status. Despite small variations in the number of citations, all recognize in this order shading, erosion control, and maintenance of air quality (Figure 7(b)). Marital status has very little influence on the exploitation of the indirect benefits of the Djoumouna periurban forest. This notion, as is very often the case, is intimately correlated with the benefits derived from the tree enthroned in its housing concession. With regard to the benefits derived from the regulation services of the Djoumouna periurban forest, the Kruskal-Wallis test ( $P$ value $0.40>0.05)$ does not reveal any significant difference between the individuals forming the different age groups. This 


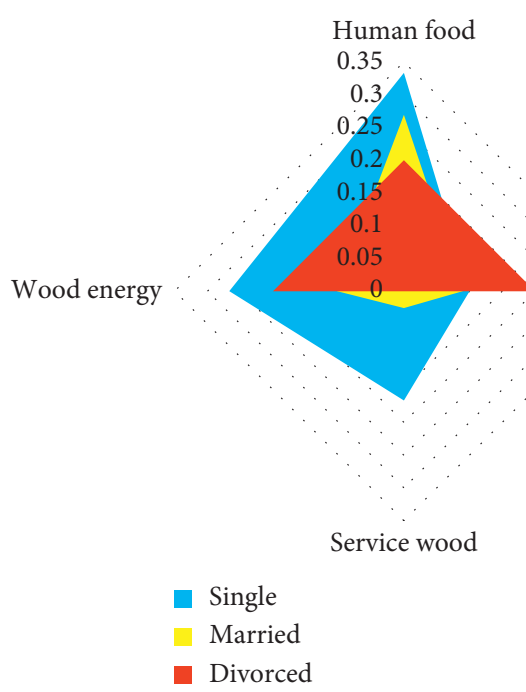

(a)

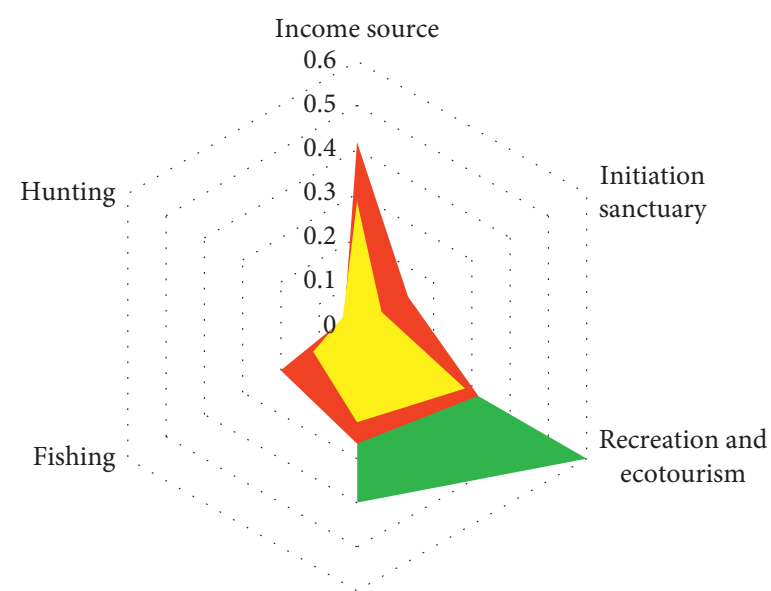

(b)
Erosion
control

Windbreak

Divorced

Single

Married

Source of inspiration

Divorced

a Single

Married

(c)

Figure 7: Perception of ecosystem services by marital status (\%): frequency of citation of sampling services (a); frequency of citation of regulatory services (b); frequency of citation of sociocultural services (c).

value in intangibles can be difficult to apprehend for "ordinary people.". Thus, its relationship to marital status is not easy to assess.

9.3. Sociocultural Services. In relatively little difference in the number of citations, the residents of the Djoumouna forest choose recreation and ecotourism as sources of inspiration and income (Figure $7(\mathrm{c})$ ). In relation to marital status, divorced and single people form the group that has more pressure on ecosystem services. As is the case with provisioning services, single people are most dependent on benefits from urban forest ecosystems. About the sociocultural services generated by the Djoumouna periurban forest, the Kruskal-Wallis test $(P$ value $0.35>0.05)$ does not reveal any significant differences between individuals of different age groups. The observation of statistical data does not seem to reflect the observed facts. In spite of the very low level of user attendance, these results could highlight unadmitted societal facts.

\section{Perception of Ecosystem Services as a Function of Socioprofessional Activity}

10.1. Provisioning Services. The majority of students cites the provisioning services selected. Preference is given to food, fuelwood, and service wood (Figure 8(a)). The same trend is observed for all the others, but generally to a much lesser degree of citation. The tendency to exploit provisioning ecosystem services is greater among students than among other socioprofessional categories. This social stratum, which is often poor, uses the services provided by the 


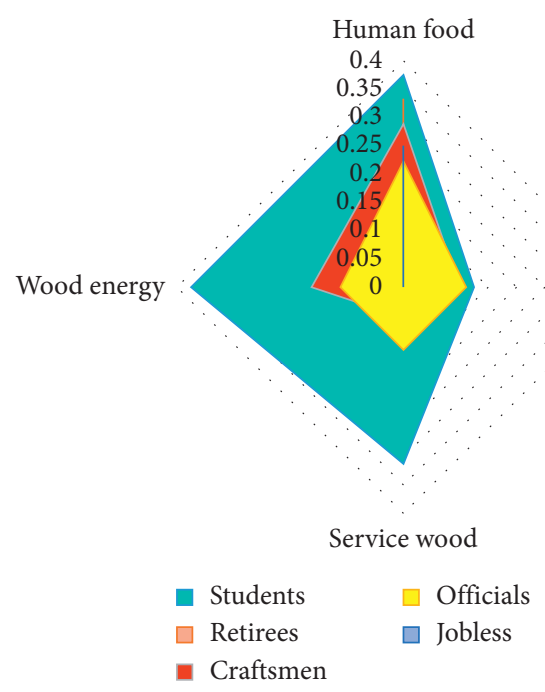

(a)

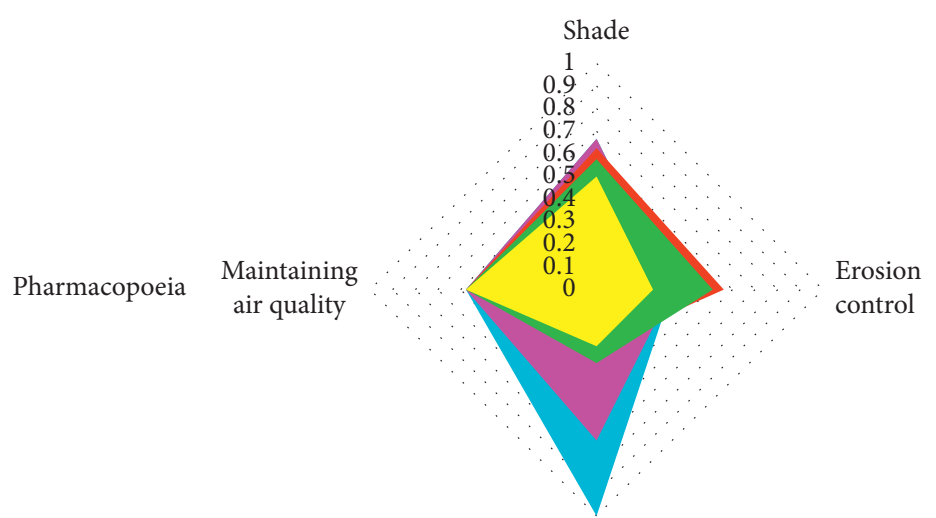

Windbreak role
- Retirees
Officials
Craftsmen
Jobless

Students

(b)

Source of

inspiration

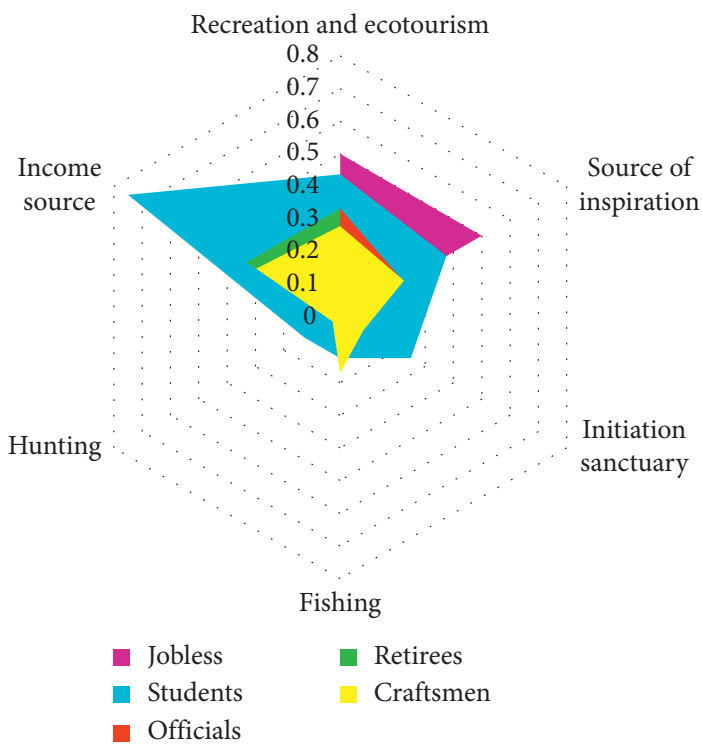

(c)

Figure 8: Perception of ecosystem services by socioprofessional activity (\%): frequency of citation of sampling services (a); frequency of citation of regulatory services (b); frequency of citation of sociocultural services (c).

Djoumouna forest to cover the financial needs inherent to their student survival. In spite of the floristic and specific poverty of this ecosystem, this social stratum, which takes in far more than others, accentuates the phenomenon of anthropization and thus the erosion of resources. With regard to the provisioning services generated by the Djoumouna periurban forest, the Kruskal-Wallis test $(P$ value $0.43>0.05)$ does not show significant differences within the socioprofessional categories.

10.2. Regulatory Services. Maintaining air quality and acting as a windbreak are the control functions emphasized by retirees and partly by unemployed residents (Figure 8(b)). It should be noted that the proportion of citations is around $60 \%$ of the ecosystem services of shade and erosion control for students, retirees, and civil servants. Although retirees and civil servants are the only ones to stand out on the windbreak function, the level of perception of ecosystem services is subidentical for all. These nonpalpable services are best perceived by people with at least a secondary education, despite the known empirical management of these facts. The Kruskal-Wallis test $(P$ value $0.70>0.05)$ reveals that there is no significant difference between the socioprofessional categories when exploiting the benefits of the regulation services provided by the Djoumouna periurban forest.

10.3. Sociocultural Services. Unemployed local residents carry ecosystem services such as inspiration, recreation, and ecotourism (Figure 8(c)). In this category of services, the students' footprint in the exploitation of services provided 
by the Djoumouna periurban forest is well marked. In view of their vulnerability, the students rake in forest resources that are barely available to meet their needs, as in the case of provisioning services. In contrast, students speculate on the source of income with $50 \%$ citations. However, retirees' contribution is noticed for services such as inspiration, recreation, and ecotourism. Analysis of the citation rates reveals a dispersion of views on the perception of these ecosystem services. Thus, regardless of the ecosystem service or the status of the riparian, the number of citations is barely around $30 \%$. According to socioprofessional categories, the Kruskal-Wallis test $(P$ value $0.23>0.05)$ reveals that no significant difference is noted in the exploitation of regulation services derived from the Djoumouna periurban forest.

\section{Discussion}

11.1. Trends in Ecosystem Services. The data collected clearly show that the Djoumouna forest occupies a cardinal position in meeting the daily needs of the surrounding populations. In relation to the three ecosystem categories, the main services retained derive from harvesting, in no order of importance, are food, fuelwood, pharmacopoeia, and service wood [47]. Certain forest products often provide these services, separately [48-50]. By considering social classes, the study reveals unexpected facts about the perception of ecosystem goods and services by the population. The latter most often ranks regulating services ahead of sociocultural services and provisioning services. Despite the scarcity of these products in this ecosystem, this observation could be a first highlighting the ecological awareness of the people living in the vicinity of this forest ecosystem $[48,50,51]$. In most cases, studies that have addressed all categories of ecosystem services have mainly reasoned in terms of plant communities and have rather sought to list the species that contribute to the different categories of ecosystem services; this does not allow the identification of all the ecosystem services associated with an entire forest area [52].

11.2. Dependence of the Population on the Forest. The Djoumouna forest provides livelihoods for local residents by providing them with NTFPs of both plant and animal origin. As is most often the case, the food component constitutes the first service in the provisioning services category $[10,51]$. In spite of the provisioning services, these NTFPs are also a source of income for local residents who are heavily involved in the trade of these products. The source of income ranks first in the category of sociocultural services, which highlights the dependency of the populations on this forest area requiring sustainable management [53-55]. In addition to the abovementioned aspects, the Djoumouna periurban forest remains a tourist and recreational centre for more than one riparian $[56,57]$. This attractiveness, underpinned by various reasons, increases its vulnerability to ever-increasing anthropogenic pressure [41, 58-61].

The people most dependent on the Djoumouna forest are men, especially those aged 15 and 25 and those over 45 . The reasons for this are many and varied. The foundations are to be found in the functioning and dynamism, and even antagonism, of worldly and rural societies.

11.3. Population and Forest Dependence. People's perception of the ecosystem services provided by the Djoumouna periurban forest decreases in proportion to their overall distance from the forest. However, the level of perception of regulation services, even in the very remote area, is not marginal. This observation authenticates that the regulatory functions provided by this ecosystem impact beyond the zone of influence of this study. The scope of the regulatory services provided by the Djoumouna periurban forest is not limited to the local scale but can be regional [10].

The consideration of remoteness as a distinguishing criterion is a major data showing that the highest use values are associated with the first zones. These values reflect the strong relationship of dependence of the populations of the nearby areas on the forest [37]. The low levels of use values in the remote and very remote areas would be explained, notwithstanding distance and socioprofessional categories, by the poverty and scarcity of nonligneous forest products (NTFPs), especially animal products in this ecosystem. As such, the Djoumouna periurban forest is not attractive to the residents of Zones 3 and 4, who are usually overtaken by the cooperators of Zones 1 and 2.

Based on the data collected on the direct and indirect benefits generated by the Djoumouna periurban forest, local residents derive an added value associated with intangible compensation. This value confers a high use value and a high fidelity level to the ecosystem services associated with this ecosystem [62].

11.4. Analysis of Anthropogenic Pressure. Many people around the world, particularly in developing countries, still rely heavily on wood energy for cooking and heating [63]. This observation is also true for the residents of the Djoumouna periurban forest. Indeed, the majority of households surveyed in this study use dead wood as their main source of domestic energy [41-65]. Furthermore, service wood is the most recent ecosystem service retained in the category of harvesting services. Indeed, the private forest status of the Djoumouna periurban woody formation strictly prohibits the artisanal exploitation of wafers or service wood [62].

The traditional pharmacopoeia, due to the prohibitive costs of modern medicine, is the primary recourse of more than one resident $[66,67]$. The therapeutic virtues of the 9 species selected by the survey being proven, several of them present high informant consensus factor values. Examples include Quassia africana and Sarcocephalus latifolius whose therapeutic value is not in doubt $[68,69]$. The values of the informant consensus factor can be interpreted as indicating anthropogenic pressure on these taxa [41, 59-61]. Indeed, Quassia africana and Sarcocephalus latifolius, which are very abundant and easily accessible, are much in demand for their antimalarial properties. However, the exploitation of savannah species such as Sarcocephalus latifolius, Aframomum 
stipulatum, and Senna occidentalis proves that local residents do not depend solely on the Djoumouna forest.

The informant consensus factor would be a discriminating element facilitating a synoptic view of the diversity of ecosystem services at the forest scale and an assessment of the relative importance of each of the categories represented $[41,51,70]$.

\section{Conclusion}

The study highlights the ecosystem services provided by the Djoumouna periurban forest to the riparian populations. Their perception and the uses they make of it are the foundation of the work. The provisioning services, which are most valued by the riparian populations, provide both plant and animal nontimber forest products (NTFPs). In addition to the NTFPs that have a palpable value, the influence of this woody formation via the regulating services clearly exceeds the zonal situation.

In terms of the degree of exploitation of this ecosystem, the populations in the first areas (near and very near) are more dependent than those in the remote and very remote areas. Considering gender and age groups, men derive a greater share of benefits than women, whereas 15- and 25year-olds and 45-year-old and over represent the fringe that frequents the forest the most. In social terms, the majority of the occupants are secondary school students, single people, and finally old retirees, especially divorced people with a university background.

Finally, the Djoumouna periurban forest is under strong anthropogenic pressure due to the abusive and uncontrolled use by local residents, which leads to a decrease in biodiversity and with it a decrease in the value of ecosystem services. Data on bioecological and ethnobotanical knowledge coupled with data on the perception of ecosystem services by local residents would be assets for developing a strategy for the conservation and sustainable management of biodiversity in the urban and periurban forests of Brazzaville. This would be a guarantee of a resilient city and the assurance of better living conditions for its citizens.

\section{Data Availability}

The dissertation and the database are available and can be consulted without restrictions, free of charge on request, at the IRF and at the Ecole Normale Supérieure of the Université Marien Ngouabi.

\section{Conflicts of Interest}

The authors declare that they have no conflicts of interest.

\section{References}

[1] C. De Wasseige, M. Tadoum, R. Eba'Atyi, and C. Doumenge, "The forests of the Congo Bassin," Forests and Climate Change, Weyrich, Lutherville, MD, USA, 2015.

[2] FOSA, Etudes prospectives du secteur forestier en Afrique, FOSA, République du Congo, 2007.
[3] V. Kimpouni, P. Mbou, G. Gakosso, and M. Motom, "Biodiversité floristique du sous-bois et régénération naturelle de la forêt de la Patte d'Oie de Brazzaville, Congo," International Journal of Biological and Chemical Sciences, vol. 7, no. 3, pp. 1255-1270, 2013.

[4] UICN, L'Atlas pour la Conservation des Forêts Tropicales d'Afrique, UICN, Gland, Suisse, 1996.

[5] FAO, Responsible Management of Planted Forests: Voluntary Guidelines, Planted Forests and Trees Working, Rome, Italy, 2006.

[6] G. C. Daily, S. Alexander, P. R. Ehrlich et al., "Ecosystem services: benefits supplied to human societies by natural ecosystems," Issues in Ecology, vol. 2, 1997.

[7] C. Barnaud, M. Antona, and J. Marzin, "Vers une mise en débat des incertitudes associées à la notion de service écosystémique," VertigO, vol. 11, no. 1, p. 22, 2011, http:// vertigo.revues.org/10905.

[8] R. S. De Groot, M. A. Wilson, and R. M. J. Boumans, "A typology for the classification, description and valuation of ecosystem functions, goods and services," Ecological Economics, vol. 41, no. 3, pp. 393-408, 2002, http://www.elsevier. com/locate/ecolecon.

[9] MEA, "Rapport de synthèse de l'évaluation des écosystèmes pour le millénaire," Millenium Ecosystem Assessment, vol. 59, 2005.

[10] S. Shackleton, A. Chinyimba, P. Hebinck, C. Shackleton, and H. Kaoma, "Multiple benefits and values of trees in urban landscapes in two towns in northern South Africa," Landscape and Urban Planning, vol. 136, pp. 76-86, 2015.

[11] C. Dobbs, F. J. Escobedo, and W. C. Zipperer, "A framework for developing urban forest ecosystem services and goods indicators," Landscape and Urban Planning, vol. 99, no. 3-4, pp. 196-206, 2011.

[12] D. J. Nowak, D. E. Crane, and J. C. Stevens, "Air pollution removal by urban trees and shrubs in the United States," Urban Forestry \& Urban Greening, vol. 4, no. 3-4, pp. 115-123, 2006.

[13] N. C. Poudyal, J. P. Siry, and J. M. Bowker, "Urban forests' potential to supply marketable carbon emission offsets: a survey of municipal governments in the United States," Forest Policy and Economics, vol. 12, no. 6, pp. 432-438, 2010.

[14] A. A. Alvey, "Promoting and preserving biodiversity in the urban forest," Urban Forestry \& Urban Greening, vol. 5, no. 4, pp. 195-201, 2006.

[15] C. D. Ives, P. E. Lentini, C. G. Threlfall et al., "Cities are hotspots for threatened species," Global Ecology and Biogeography, vol. 25, no. 1, pp. 117-126, 2016.

[16] J. Colding and S. Barthel, "The potential of 'Urban Green Commons' in the resilience building of cities," Ecological Economics, vol. 86, pp. 156-166, 2013.

[17] B. Chevassus-au-Louis, J.-M. Salles, S. Bielsa, D. Richard, G. Martin, and J.-L. Pujol, "Approche économique de la biodiversité et des services liés aux écosystèmes," in Contribution à la décision publique, Rapports et DocumentsCentre d'Analyse Stratégique, Paris, France, 2009.

[18] F. Skoulika, M. Santamouris, D. Kolokotsa, and N. Boemi, "On the thermal characteristics and the mitigation potential of a medium size urban park in Athens, Greece," Landscape and Urban Planning, vol. 123, pp. 73-86, 2014.

[19] T. O. Lougbegnon, "Évaluation de la diversité des essences forestières urbaines de la ville de Porto-Novo et leurs utilisations par les populations locales," Géographie du laboratoire de Leïd, vol. 21, pp. 326-341, 2013. 
[20] A. Sæbø, S. Janhall, S. W. Gawronski, and H. M. Hanslin, "Urban forestry and pollution mitigation," in Routledge Handbook of Urban Forestry, F. Ferrini, C. Konijnendijk van den Bosch, and A. Féds, Eds., Routledge, Londres, UK, 2017.

[21] C. Ikama Openga, "Dynamique de la perte du couvert forestier de la réserve forestière de la Patte d'Oie (Brazzaville, pour la période de 1946 à 2014)," University Marien Ngouabi, Brazzaville, Congo, Mémoire Master, 2013.

[22] V. Kimpouni, E. Motom, and E. Apani, "Analyse Phytoécologique de la Flore Ligneuse de la Haute Sangha (République du Congo)," Adansonia, vol. 35, no. 1, pp. 107-134, 2013.

[23] B. Tiokeng, P. Mapongmetsem, V. Nguetsop, and W. Tacham, "Biodiversité floristique et régénération naturelle sur les Hautes Terre de Lebialem (Ouest Cameroun)," International Journal of Biological and Chemical Sciences, vol. 9, no. 1, pp. 56-68, 2015.

[24] K. S.-H. Peh, A. Balmford, R. B. Bradbury et al., Toolkit for Ecosystem Service Site-Based Assessment, p. 31, Bird Life International, Dortmund, Germany, 2014.

[25] C. M. Massamba-Makanda, "Phytodiversité et paramètres structuraux de la forêt périurbaine de la Djoumouna," University of Marien Ngouabi, Brazzaville, Congo, Mémoire Master, 2017.

[26] L. Makany, J. Trouillet, B. Cros, and J. P. Grillot, Recherches Bioécologiques dans la région de Yaka-Yaka (Congo). Présentation du milieu, Annales de l'université de Brazzaville, Brazzaville, Congo, 1977.

[27] B. Descoings, Phytogéographie: esquisse phytogéographique du Congo: Atlas du CongoORSTOM, Bondy (I carte couleurs 1 :2000000), Bondy, France, 1969.

[28] M.-J. Samba-Kimbata, "Le climat du bas-Congolais," Thèse $3^{\text {eme }}$ Cycle, Géographie, pp. 200-280, Université de Dijon, Dijon, France, 1978.

[29] M.-J. Samba-Kimbata and M. Mpounza, "Végétation et faune du Congo," in Atlas du Congo, P. Vennetier, Ed., éditions J. A., Paris, France, 2001.

[30] G. Samba, Le Congo-Brazzaville: Climat et environnement, Éditions L'Harmattan, Paris, France, 2014.

[31] L. Makany, Végétation des Plateaux Téké (Congo), Collection des travaux de l'Université de Brazzaville, Brazzaville, Congo, 1976.

[32] J. Koechlin, La Végétation des Savanes dans le Sud de la République du Congo, IRSC-ORSTOM, Paris, France, 1961.

[33] D. Schwartz, Les sols des environs de Brazzaville et leur utilisation, ORSTOM, Pointe-Noire, Congo, 1987.

[34] E. S. Miabangana, "Etude de quelques plantes utiles de la forêt de la Djoumouna," University of Marien Ngouabi, Brazzaville, Congo, Mémoire Master, 1998.

[35] APG IV, "An update of the angiosperm phylogeny group classification for the orders and families of flowering plants," Botanical Journal of the Linnean Society, vol. 181, pp. 1-20, 2016.

[36] J.-P. Lebrun and L. Stork, Enumération des plantes a fleur d'Afrique tropicale, Genève: Editions des conservatoires et Jardin botaniques de Genève, Geneva, Swizerland, 2015.

[37] S. D. Dieng, M. Diop, A. Goudiaby et al., "Caractérisation des services écosystémiques fournis par Cordyla pinnata dans la périphérie de la Forêt classée de Patako au Sénégal," VertigO, vol. 16, no. 2, pp. 41-49, 2016, http://vertigo.revues.org/17634.

[38] L. Hein, K. van Koppen, R. S. de Groot, and E. C. van Ierland, "Spatial scales, stakeholders and the valuation of ecosystem services," Ecological Economics, vol. 57, no. 2, pp. 209-228, 2006.
[39] P. Puydarrieux and J. Devaux, Quelle évaluation économique pour les Services écosystémiques rendus par les prairies en France métropolitaine? Commissariat général sur le Développement Durable, Service de l'économie, de l'évaluation et de l'intégration du développement durable, Paris, France, 2013.

[40] O. Phillips, A. H. Gentry, C. Reynel, P. Galvez-Durand, and C. B. Gavez-Durand, "Quantitative ethnobotany and Amazonian conservation," Conservation Biology, vol. 8, no. 1, pp. 225-248, 1994.

[41] A. A. Ayantunde, P. Hiernaux, M. Briejer, H. Udo, and R. Tabo, "Uses of local plant species by agropastoralists in South-western Niger," Ethnobotany Research and Applications, vol. 7, pp. 053-066, 2009, http://www.erajournal.org/ ojs/index.php/era/article/view/297/194.

[42] M. E. Dossou, G. L. Houessou, O. T. Lougbégnon, A. H. B. Tenté, and J. T. C. Codjia, "Étude ethnobotanique des ressources forestières ligneuses de la forêt marécageuse d'Agonvè et terroirs connexes au Bénin," Tropicultura, vol. 30, no. 1, pp. 41-48, 2012.

[43] T. K. Sop, J. Oldeland, F. Bognounou, U. Schmiedel, and A. Thiombiano, "Ethnobotanical knowledge and valuation of woody plants species: a comparative analysis of three ethnic groups from the sub-Sahel of Burkina Faso," Environment, Development and Sustainability, vol. 14, no. 5, pp. 627-649, 2012.

[44] M. Heinrich, A. Ankli, B. Frei, C. Weimann, and O. Sticher, "Medicinal plants in Mexico: healers' consensus and cultural importance," Social Science \& Medicine, vol. 47, no. 11, pp. 1859-1871, 1998.

[45] A. Andrade-Cetto and M. Heinrich, "From the field into the lab: useful approaches to selecting species based on local knowledge," Frontiers in Pharmacology, vol. 2, p. 20, 2011.

[46] M. Z. Uddin and M. A. Hassan, "Determination of informant consensus factor of ethnomedicinal plants used in Kalenga forest, Bangladesh," Bangladesh Journal of Plant Taxonomy, vol. 21, no. 1, pp. 83-91, 2014.

[47] G. Serpantié, P. Méral, and C. Bidaud, "Des bienfaits de la nature aux services écosystémiques," VertigO, vol. 12, no. 3, http://vertigo.revues.org/12924, 2012.

[48] B. Belem, C. S. Olsen, I. Theilade et al., "Identification des arbres hors forêt préférés des populations du Sanmatenga (Burkina Faso)," Bois et Forêts des Tropiques, vol. 298, no. 4, pp. 53-64, 2008.

[49] M. Diop, B. Sambou, A. Goudiaby, I. Guiro, and F. NiangDiop, "Ressources végétales et préférences sociales en milieu rural sénégalais," Bois et Forêts des Tropiques, vol. 310, no. 4, pp. 57-68, 2011.

[50] D. Ngom, M. M. Charahabil, O. Sarr, A. Bakhoum, and L. E. Akpo, "Perceptions communautaires sur les services écosystémiques d'approvisionnement fournis par le peuplement ligneux de la Réserve de Biosphère du Ferlo (Sénégal)," VertigO, vol. 13, no. 2, http://vertigo.revues.org/15188, 2014.

[51] O. Gning, O. Sarr, M. Gueye, L. Akpo, and P. Ndiaye, "Valeur socio-économique de l'arbre en milieu malinké (Khossanto, Sénégal)," Journal of Applied Biosciences, vol. 70, no. 1, pp. 5617-5631, 2013.

[52] I. Ouédraogo, B. M. I. Nacoulma, K. Hahn, and A. Thiombiano, "Assessing ecosystem services based on indigenous knowledge in south-eastern Burkina Faso (West Africa)," International Journal of Biodiversity Science, Ecosystem Services \& Management, vol. 9, pp. 950-980, 2014.

[53] J. P. Amigues, B. Desaigues, and Q. H. Vuong, "L’Évaluation contingente: controverses et perspectives," Cahiers 
d'Économie et de Sociologie rurales, vol. 39, no. 40, pp. 123150, 1996.

[54] V. Scherrer, Réinventer la chasse pour le XXIe siècle, Rapport au Conseil économique et social, Rome, Italy, 2002.

[55] FAO, The State of Food and Agriculture, FAO, Rome, Italy, 2007.

[56] D. W. Pearce and C. G. T. Pearce, "The value of forest ecosystems," CDB Technical Series, Secretariat of the Convention on Biological Diversity, New York, NY, USA, 2001.

[57] K. G. Willis, G. Garrod, and R. Scarpa, The Social and Environmental Benefits of Forests in Great Britain, http://www. forestry.gov.uk/website/PDF.nsf/pdf/sebreport0703.pdf/ \$FILE/sebreport\%200703.pdf, Report to Forestry Commission, Edinburgh, Scotland, 2003, http://www.forestry.gov.uk/ website/PDF.nsf/pdf/sebreport0703.pdf/\$FILE/sebreport\% 200703.pdf.

[58] A. Huet and G. Saez, Le règne de loisirs, culturels et sportifs, dynamiques socio-spatiales, Edition de l'aube Dakar, Dakar, Senegal, 2002.

[59] L. Gazzaneo, R. De Lucena, and U. De Albuquerque, "Knowledge and use of medicinal plants by local specialists in a region of Atlantic Forest in the state of Pernambuco (Northeastern Brazil)," Journal of Ethnobiology and Ethnomedicine, vol. 1, no. 1, pp. 9-8, 2005.

[60] O. Sarr, D. Ngom, A. Bakhoum, and L. E. Akpo, "Dynamique du peuplement ligneux dans un parcours agrosylvopastoral du Sénégal," VertigO, vol. 13, no. 2, pp. 1-16, 2013.

[61] M. Dedoncker, "Structure, dynamique et utilisations de la ressource ligneuse dans le Ferlo (Sénégal)," Université Catholique de Louvain, Louvain, Belgium, Mémoire Bioingénieur, 2013.

[62] A. A. Diatta, N. Ndour, A. Manga et al., "Services ecosystémiques du parc agroforestier à Cordyla pinnata (Lepr. ex A. Rich.) Milne-Redh. dans le Sud du Bassin Arachidier (Sénégal)," International Journal of Biological and Chemical Sciences, vol. 10, no. 6, pp. 2511-2525, 2016.

[63] J. A. Fuwape and J. C. Onyekwelu, "Urban forest development in West Africa: benefits and challenges," Journal of Biodiversity and Ecological Sciences, vol. 1, pp. 77-94, 2011.

[64] J. Friedman, Z. Yaniv, A. Dafni, and D. Palewitch, “A preliminary classification of the healing potential of medicinal plants, based on a rational analysis of an ethnopharmacological field survey among Bedouins in the Negev Desert, Israel," Journal of Ethnopharmacology, vol. 16, no. 2-3, pp. 275-287, 1986.

[65] V. Kimpouni, J. D. D. Nzila, and H. F. Kaya, "Urban forestry and ecosystem services in the city of Dolisie (Congo)," American Journal of Agriculture and Forestry, vol. 7, no. 2, pp. 53-65, 2019.

[66] World Health Organization, Traditional Medicine Strategy 2002-2005, World Health Organization, Geneva, Switzerland, 2002, http://www.who.int/medicines/library/trm\%20trat\% 20eng.pdf.

[67] V. Kimpouni, J. C. Mamboueni, F. G. Mboussy Tsoungould, and E. N. Mikoko, "Environment and livelihood of the Kouni community of the Kayes sub-prefecture (Bouenza, Congo)," Ethnobotany Research and Applications, vol. 18, no. 44, pp. 1-15, 2019.

[68] G. F. Nsonde Ntandou, V. Kimpouni, L. D. Dianzitoukoulou Matsima, and A. A. Abena, "Evaluation of antipyretic and analgesic effects of Alchornea cordifolia schum. \& Thonn. (Euphorbiaceae) and Quassia africana Baill (Simaroubaceae)," International Journal of Sciences, vol. 9, no. 1, pp. 1-7, 2020, http://www.ijsciences.com/pub/issue/2020-01/.
[69] M. Badiaga, Etude ethnobotanique, phytochimique et activités biologiques de Nauclea latifolia Smith, une plante médicinale africaine récoltée au Mali, Université Blaise Pascal, ClermontFerrand, France, 2011.

[70] A. Cheikhyoussef, M. Shapi, K. Mu, H. Ashekele, and K. Matengu, "Ethnobotanical study of indigenous knowledge on medicinal plant use by traditional healers in Oshikoto region, Namibia," Journal of Ethnobiology and Ethnomedicine, vol. 7, no. 1, pp. 7-10, 2011. 